\title{
Reactivity of vinyl and alkynyl zirconium complexes with the di-ansa-[1,1',2,2'-bis(dimethylsilanediyl) dicyclopentadienyl] ligand
}

\author{
Francisco J. Fernández, Mikhail V. Galakhov, Pascual Royo * \\ Departamento de Química Inorgánica, Facultad de Ciencias, Campus Universitario, Edificio de Farmacia, Universidad de Alcalá de Henares, \\ E-28871 Alcalá de Henares, Spain
}

Received 28 May 1999; accepted 22 October 1999

\begin{abstract}
Vinylation of the chloro-ethyl and dichloro zirconium complexes $\left[\mathrm{Zr}\left(\mathrm{CpSi}{ }_{2} \mathrm{Cp}\right) \mathrm{ClX}\right]\left(\mathrm{CpSi}_{2} \mathrm{Cp}=1,1^{\prime}, 2,2^{\prime}-\left(\mathrm{SiMe}_{2}\right)_{2}\left(\eta^{5}-\mathrm{C}_{5} \mathrm{H}_{3}\right)_{2}\right.$; $\mathrm{X}=\mathrm{Et}, \mathrm{Cl})$ with one or two equivalents of $\mathrm{Mg}\left(\mathrm{CH}=\mathrm{CH}_{2}\right) \mathrm{Cl}$ gave the new zirconacyclopentane $\left[\mathrm{Zr}\left(\mathrm{CpSi}{ }_{2} \mathrm{Cp}\right)\left\{\eta^{2}-\right.\right.$ $\left.\left.\mathrm{CH}_{2}-\left(\mathrm{CH}_{2}\right)_{2}-\mathrm{CH}_{2}\right\}\right]$ and $\left(\eta^{4}\right.$-butadiene)zirconium $\left[\mathrm{Zr}\left(\mathrm{CpSi}{ }_{2} \mathrm{Cp}\right)\left\{\eta^{4}\right.\right.$-(butadiene)\}] complexes, respectively. Addition of a toluene solution of $\mathrm{PhC} \equiv \mathrm{CPh}$ to the zirconacyclopentane compound afforded the zirconacyclopentadiene derivative $\left[\mathrm{Zr}\left(\mathrm{CpSi}{ }_{2} \mathrm{Cp}\right)\left\{\eta^{2}-\right.\right.$ $(\mathrm{CPh}=\mathrm{CPh}-\mathrm{CPh}=\mathrm{CPh})\}]$. Reaction of the chloro-ethyl zirconium complex with $\mathrm{LiC} \equiv \mathrm{CPh}$ afforded the alkynyl compound $\left[\mathrm{Zr}\left(\mathrm{CpSi}{ }_{2} \mathrm{Cp}\right) \mathrm{Et}(\mathrm{C} \equiv \mathrm{CPh})\right]$ which reacted with $\mathrm{CN}\left(2,6-\mathrm{Me}_{2} \mathrm{C}_{6} \mathrm{H}_{3}\right)$ to give the insertion product $\left[\mathrm{Zr}\left(\mathrm{CpSi}{ }_{2} \mathrm{Cp}\right)(\mathrm{C} \equiv \mathrm{CPh})\left\{\eta^{2}-\right.\right.$ $\left.\left.\mathrm{C}(\mathrm{Et})=\mathrm{N}\left(2,6-\mathrm{Me}_{2} \mathrm{C}_{6} \mathrm{H}_{3}\right)\right\}\right]$. Reactions of the chloro-ethyl $\left[\mathrm{Zr}\left(\mathrm{CpSi}{ }_{2} \mathrm{Cp}\right) \mathrm{EtCl}\right]$ and alkynyl-ethyl $\left[\mathrm{Zr}\left(\mathrm{CpSi}{ }_{2} \mathrm{Cp}\right) \mathrm{Et}(\mathrm{C} \equiv \mathrm{CPh})\right]$ complexes with the Lewis acid $\mathrm{B}\left(\mathrm{C}_{6} \mathrm{~F}_{5}\right)_{3}$ yielding various cationic species have been monitored by ${ }^{1} \mathrm{H}-\mathrm{NMR}$ spectroscopy. The new complexes reported and their intermediates have been identified by IR and ${ }^{1} \mathrm{H}-$ and ${ }^{13} \mathrm{C}-\mathrm{NMR}$ spectroscopy. (C) 2000 Elsevier Science S.A. All rights reserved.
\end{abstract}

Keywords: Zirconium; Alkenyl; Alkynyl; Alkylzirconacycles

\section{Introduction}

Bridged dicyclopentadienyl Group 4 metal complexes are particularly interesting systems, used extensively as active and stereoselective catalysts for olefin polymerization processes [1]. Their activity is increased [2] when silyl-substituted rings are used, and for this reason many studies on the synthesis and reactivity of ansa metallocenes of Group 4 metals with one [3] or two [4] dimethylsilyl bridges have been reported in recent years. Most of the studies concerning applications in olefin polymerization have focused on alkyl derivatives without $\beta$-hydrogen-containing alkyl groups, because of their higher stability. We recently reported [5] the synthesis and structure of $\beta$-hydrogen containing alkyl dicyclopentadienyl zirconium complexes and some aspects of their reactivity.

\footnotetext{
* Corresponding author. Tel.: +34-91-8854765; fax: + 34-918854683.

E-mail address: proyo@inorg.alcala.es (P. Royo)
}

Dicyclopentadienyl-zirconacyclopentane compounds have been prepared by reaction of different alkenes with ' $\mathrm{Cp}_{2} \mathrm{Zr}$ (alkene)' generated in situ [6] and by alkylation of $\mathrm{Cp}_{2} \mathrm{ZrCl}_{2}$ with 1,4-dilithiobutane and $\mathrm{BrMg}\left(\mathrm{CH}_{2}\right)_{4} \mathrm{MgBr}$ [7]. These reactive compounds readily undergo reductive decoupling reactions by $\mathrm{C}_{\beta}-\mathrm{C}_{\beta^{\prime}}$ bond cleavage in the presence of phosphine ligands to give the zirconium(II) species $\mathrm{Cp}_{2} \mathrm{Zr}\left(\mathrm{CH}_{2}=\mathrm{CH}_{2}\right) \mathrm{L}$ [7a] and react with different alkenes and alkynes to give new zirconacyclopentane, -pentene and -pentadiene complexes [6] which have been studied particularly as stereoselective reagents for many catalytic $[6,8]$ and stoichiometric carbon-carbon bond-forming reactions [9].

Vinyl derivatives are interesting and reactive species which provide new synthetic pathways to many related compounds. Divinyl species may rearrange to form zirconacyclopent-1-enes through $\beta$-hydrogen elimination [10] and give butadiene derivatives $[11,12]$ by $\mathrm{C}-\mathrm{C}$ coupling. The structure of such butadiene compounds has been extensively explored and their behaviour as $\eta^{4}$-diene or $\sigma^{2}$ - $\pi$-zirconacyclopent-2-ene species with a 

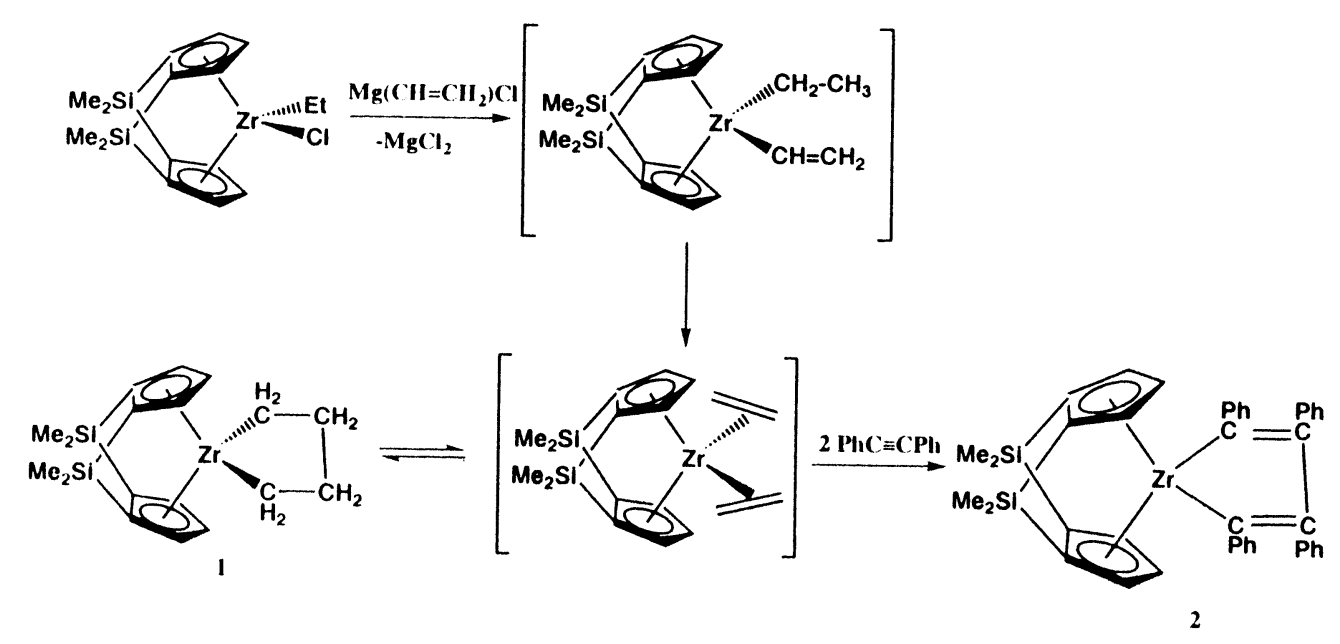

Scheme 1.

significant $\pi$-bonding contribution from the central $\mathrm{C}-\mathrm{C}$ double bond has been discussed $[13,14]$. Because of its known higher stability, we chose the bis(dimethylsilanediyl)dicyclopentadienyl $\left(\mathrm{CpSi}_{2} \mathrm{Cp}\right)$ ligand to study the behaviour of various mixed dialkyl zirconium complexes, to attempt to isolate or characterize intermediates formed during their thermal decomposition by NMR spectroscopy, and to characterize cationic species generated from their reactions with strong Lewis acids, such as $\mathrm{B}\left(\mathrm{C}_{6} \mathrm{~F}_{5}\right)_{3}$.

\section{Results and discussion}

\subsection{Reactions with $\mathrm{Mg}\left(\mathrm{CH}=\mathrm{CH}_{2}\right) \mathrm{Cl}$}

We reported [5] the isolation and thermal transformation of the $\beta$-hydrogen containing zirconium diethyl $\left[\mathrm{Zr}\left(\mathrm{CpSi}_{2} \mathrm{Cp}\right) \mathrm{Et}_{2}\right]$ derivative of the di-ansa-dicyclopentadienyl $\left[1,1^{\prime}, 2,2^{\prime}-\left(\mathrm{SiMe}_{2}\right)_{2}\left(\eta^{5}-\mathrm{C}_{5} \mathrm{H}_{3}\right)_{2}\right]=\left[\mathrm{CpSi}{ }_{2} \mathrm{Cp}\right]$ ligand. This transformation proceeds via activation of the carbon bonded $\beta$-hydrogen with elimination of ethane to give the ethylene bridged zirconium complex $\left[\mathrm{Zr}\left(\mathrm{CpSi}_{2} \mathrm{Cp}\right) \mathrm{Et}\right]_{2}\left(\mu-\mathrm{CH}_{2}=\mathrm{CH}_{2}\right)$. Hydrogen elimination from $\mathrm{sp}^{2}$ carbon centres is less favourable and therefore the use of mixed ethyl and alkenyl compounds opens new reaction pathways. When a THF solution of the chloro-ethyl complex $\left[\mathrm{Zr}\left(\mathrm{CpSi}_{2} \mathrm{Cp}\right) \mathrm{ClEt}\right]$ reacted with $\mathrm{Mg}\left(\mathrm{CH}=\mathrm{CH}_{2}\right) \mathrm{Cl}$ the expected mixed alkyl-alkenyl complex was not observed even at $-78^{\circ} \mathrm{C}$, and the zirconacyclopentane derivative $\left[\mathrm{Zr}\left(\mathrm{CpSi}_{2} \mathrm{Cp}\right)\left\{\eta^{2}\right.\right.$ $\left.\left.\left(\mathrm{CH}_{2}\right)_{4}\right\}\right]$ (1) was immediately and quantitatively formed (see Scheme 1). Formation of $\mathbf{1}$ can be explained as resulting from a concerted ethyl $\beta$-hydrogen transfer to the $\alpha$-carbon of the vinyl group located in a plane perpendicular to the equatorial metallocene plane to give the bis-ethylene complex, followed by oxidative coupling to afford the final zirconacyclopentane complex.
Complex 1 was isolated as an extremely air and moisture sensitive yellow solid. The ${ }^{1} \mathrm{H}-\mathrm{NMR}$ spectrum of 1 showed two multiplets for the $\alpha$ - and $\beta-\mathrm{CH}_{2}$ groups and one $\mathrm{ABB}^{\prime}$ spin system for two equivalent $\mathrm{C}_{5} \mathrm{H}_{3}$ rings resulting from a fast interconversion of the zirconacyclopentane. The ${ }^{13} \mathrm{C}-\mathrm{NMR}$ spectrum showed two triplets at $\delta 34.8\left({ }^{1} J_{\mathrm{C}-\mathrm{H}}=124.1 \mathrm{~Hz}\right)$ and $\delta 23.0$ $\left({ }^{1} J_{\mathrm{C}-\mathrm{H}}=125.5 \mathrm{~Hz}\right)$ typical for the $\mathrm{sp}^{3}$-carbons of the zirconacyclic system and consistent with this formulation.

When the ${ }^{1} \mathrm{H}$ - and ${ }^{13} \mathrm{C}-\mathrm{NMR}$ spectra of $\mathbf{1}$ were recorded in wet $\mathrm{C}_{6} \mathrm{D}_{6}$ the oxo-butyl complex $\left[\mathrm{Zr}\left(\mathrm{CpSi}_{2} \mathrm{Cp}\right) \mathrm{Bu}\right]_{2}(\mu-\mathrm{O})$, formed by hydrolytic opening of the zirconacycle, was observed ${ }^{1}$. However this compound could not be isolated because the reaction at a preparative level gave an unresolvable mixture of reaction products.

The di-olefin character of complex 1 (see Scheme 1) was demonstrated from its reaction in toluene with $\mathrm{PhC} \equiv \mathrm{CPh}$, which displaces the olefin to give the more stable zirconacyclopentadiene derivative $\left[\mathrm{Zr}\left(\mathrm{CpSi}_{2} \mathrm{Cp}\right)\right.$ $\left.\left\{\eta^{2}-(\mathrm{CPh}=\mathrm{CPh}-\mathrm{CPh}=\mathrm{CPh})\right\}\right]$ (2). The formation of the zirconacyclopentene $\left[\mathrm{Zr}\left(\mathrm{CpSi}_{2} \mathrm{Cp}\right)\left\{\eta^{2}-\left(\mathrm{CPh}=\mathrm{CPh}-\mathrm{CH}_{2}-\right.\right.\right.$ $\left.\mathrm{CH}_{2}\right)$ \}] intermediate was observed by ${ }^{1} \mathrm{H}-\mathrm{NMR}$ spectroscopy as a minor component in a sample of the solution taken after refluxing for $2 \mathrm{~h}$. Complex 2 was isolated, after refluxing for $15 \mathrm{~h}$, as a crystalline yellow solid and characterized by elemental analysis and NMR spectroscopy (see Section 4).

\footnotetext{
${ }^{1} \mathrm{NMR}$ spectra of the major component observed when solutions of 1 were recorded in wet $\mathrm{C}_{6} \mathrm{D}_{6} .{ }^{1} \mathrm{H}-\mathrm{NMR}\left(\mathrm{C}_{6} \mathrm{D}_{6}, 300 \mathrm{MHz}, \delta \mathrm{ppm}\right)$ : $\delta 6.78\left(\mathrm{~m}, 4 \mathrm{H}, \mathrm{C}_{5} \mathrm{H}_{3}\right), 6.51\left(\mathrm{~m}, 4 \mathrm{H}, \mathrm{C}_{5} \mathrm{H}_{3}\right), 6.09\left(\mathrm{~m}, 4 \mathrm{H}, \mathrm{C}_{5} \mathrm{H}_{3}\right), 1.82$, 1.16, 1.20, $0.89(4 \mathrm{~m}, 9 \mathrm{H}, \mathrm{Bu}), 0.76\left(\mathrm{~s}, 6 \mathrm{H}, \mathrm{SiMe}_{2}\right), 0.60(\mathrm{~s}, 6 \mathrm{H}$, $\left.\mathrm{SiMe}_{2}\right), 0.52$ (s, 6H, SiMe $), 0.27$ (s, 6H, SiMe $)$ ). ${ }^{13} \mathrm{C}-\mathrm{NMR}\left(\mathrm{C}_{6} \mathrm{D}_{6}, 75\right.$ $\mathrm{MHz}, \delta \mathrm{ppm}): \delta 132.0\left(\mathrm{C}_{5} \mathrm{H}_{3}\right), 129.8\left(\mathrm{C}_{5} \mathrm{H}_{3}\right), 120.4\left(\mathrm{C}_{5} \mathrm{H}_{3} \mathrm{C}_{i p s o}\right), 111.7$ $\left(\mathrm{C}_{5} \mathrm{H}_{3} \mathrm{C}_{\text {ipso }}\right), 109.8\left(\mathrm{C}_{5} \mathrm{H}_{3}\right), 42.0(\mathrm{C} \alpha, \mathrm{Bu}), 37.6(\mathrm{C} \beta, \mathrm{Bu}), 30.9(\mathrm{C} \gamma$, $\mathrm{Bu}), 14.4(\mathrm{C} \delta, \mathrm{Bu}), 2.7\left(\mathrm{SiMe}_{2}\right), 2.4\left(\mathrm{SiMe}_{2}\right),-2.7\left(\mathrm{SiMe}_{2}\right),-4.7$ $\left(\mathrm{SiMe}_{2}\right)$.
} 
The reaction of $\left[\mathrm{Zr}\left(\mathrm{CpSi}_{2} \mathrm{Cp}\right) \mathrm{Cl}_{2}\right]$ [4b] with two equivalents of $\mathrm{Mg}\left(\mathrm{CH}=\mathrm{CH}_{2}\right) \mathrm{Cl}$ in a sealed tube was monitored by ${ }^{1} \mathrm{H}-\mathrm{NMR}$ spectroscopy in THF- $d_{8}$. No reaction was observed at $-78^{\circ} \mathrm{C}$ but the divinyl complex $\left.\left[\mathrm{Zr}\left(\mathrm{CpSi}_{2} \mathrm{Cp}\right)\left(\mathrm{CH}=\mathrm{CH}_{2}\right)_{2}\right\}\right]$ was quantitatively formed after $5 \mathrm{~min}$ at $-50^{\circ} \mathrm{C}$, as evidenced by the ${ }^{1} \mathrm{H}-\mathrm{NMR}$ spectrum of this solution which showed two singlets for the exo and endo silicon-methyl groups, the expected $\mathrm{ABB}^{\prime}$ spin system for the cyclopentadienyl ring protons, and an $\mathrm{ABX}$ spin system for both equivalent vinyl groups $\left({ }^{3} J_{\text {trans }}=21.2,{ }^{3} J_{\text {cis }}=15.4\right.$ and ${ }^{2} J=2.6$ $\mathrm{Hz}$ ). The ${ }^{13} \mathrm{C}\left\{{ }^{1} \mathrm{H}\right\}$ spectrum showed the $\mathrm{C} \alpha$ signal at $\delta$ 184.7 (see Section 4). This divinyl complex was further transformed when the solution was heated to $-10^{\circ} \mathrm{C}$ and after $30 \mathrm{~min}$ at room temperature (r.t.) gave the ( $\eta^{4}$-butadiene) zirconium complex $\left[\mathrm{Zr}\left(\mathrm{CpSi}_{2} \mathrm{Cp}\right)\left\{\eta^{4}\right.\right.$ (butadiene) $\}$ ] (3) in 30\% yield, together with a mixture of unidentified products. This is the transformation expected for reductive elimination [12], although the presence of other reaction products reveals that this is not a selective reaction. The r.t. ${ }^{1} \mathrm{H}-\mathrm{NMR}$ spectrum of complex 3 shows inequivalent cyclopentadienyl rings due to a high energy barrier for the transformation shown in Scheme 2 and three multiplets for the 1,4- $\sigma$ $\eta^{2}$-2-butene ligand, one of them clearly shifted to high field $(\delta-0.80)$ corresponding to the butadiene $\mathrm{H}_{\text {anti }}$ protons. This behaviour is consistent with the pronounced $\sigma^{2}, \pi$-metallacyclopentene character reported for related compounds. The high inversion barrier has been related to the stronger bonding of the butadiene internal carbon atoms for metallocenes which have narrow $\mathrm{Cp}-\mathrm{M}-\mathrm{Cp}$ angles (ca. $119^{\circ}$, average from six $\mathrm{Zr}\left(\mathrm{CpSi}_{2} \mathrm{Cp}\right)$ structures) [14]. This formulation is consistent with the ${ }^{13} \mathrm{C}-\mathrm{NMR}$ spectrum, which shows six resonances for the ring carbons, two resonances for the $C \alpha$ and $C \beta$ of the butene ligand and two resonances for the silicon-methyl groups.

\subsection{Reaction with $\mathrm{LiC} \equiv \mathrm{CPh}$}

Reaction of the chloro-ethyl complex $\left[\mathrm{Zr}\left(\mathrm{CpSi}_{2} \mathrm{Cp}\right) \mathrm{EtCl}\right]$ with one equivalent of $\mathrm{LiC} \equiv \mathrm{CPh}$ in THF afforded the mixed alkyl-alkynyl complex $\left[\mathrm{Zr}\left(\mathrm{CpSi}{ }_{2} \mathrm{Cp}\right) \mathrm{Et}(\mathrm{C} \equiv \mathrm{CPh})\right](4)$, which was isolated as a crystalline yellow solid in $60 \%$ yield after recrystallization from pentane. $\beta$-Hydrogen elimination was not observed in a THF solution at r.t. and complex $\mathbf{4}$ was stable for short periods under these conditions. The $v(\mathrm{C} \equiv \mathrm{C}) \mathrm{IR}$ absorption at $2078 \mathrm{~cm}^{-1}$ and characteristic resonances in its ${ }^{1} \mathrm{H}-\mathrm{NMR}$ spectrum confirmed the presence of phenylalkynyl and ethyl ligands located in the equatorial plane, making the four silicon-methyl groups inequivalent, whereas an $\mathrm{ABC}$ spin system was observed for two equivalent cyclopentadienyl rings. This formulation is also consistent with the ${ }^{13} \mathrm{C}-\mathrm{NMR}$ data (see Section 4).

Complex 4 reacted in toluene with one equivalent of $\mathrm{CN}\left(2,6-\mathrm{Me}_{2} \mathrm{C}_{6} \mathrm{H}_{3}\right)$ which selectively inserted into the zirconium-ethyl bond to give the iminoacyl complex $\left[\mathrm{Zr}\left(\mathrm{CpSi}_{2} \mathrm{Cp}\right)(\mathrm{C} \equiv \mathrm{CPh})\left\{\eta^{2}-\mathrm{C}(\mathrm{Et})=\mathrm{N}\left(2,6-\mathrm{Me}_{2} \mathrm{C}_{6} \mathrm{H}_{3}\right\}\right]\right.$ (Scheme 3 ), isolated as a white solid in $90 \%$ yield. The IR $v(\mathrm{C} \equiv \mathrm{C})$ and $v(\mathrm{C}=\mathrm{N})$ absorptions were observed at

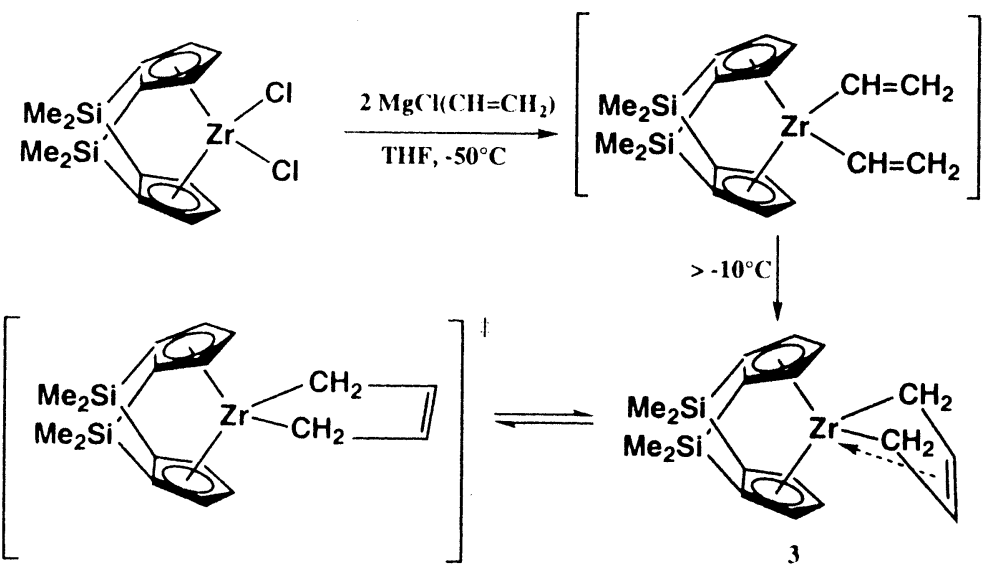

Scheme 2.
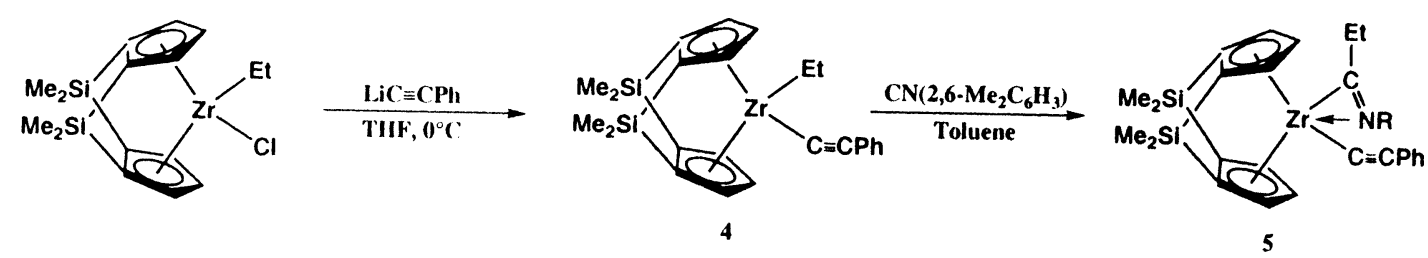

Scheme 3. 
Table 1

${ }^{1} \mathrm{H}$ - and ${ }^{13} \mathrm{C}-\mathrm{NMR}$ data for the ring $\mathrm{C}-\mathrm{H}$ and $\mathrm{Si}-\mathrm{Me}$ groups of intermediate species observed in the reactions of $\left[\mathrm{Zr}\left(\mathrm{CpSi}{ }_{2} \mathrm{Cp}\right) \mathrm{EtX}\right](\mathrm{X}=\mathrm{Cl}$, $\mathrm{C} \equiv \mathrm{CPh})$ with $\mathrm{B}\left(\mathrm{C}_{6} \mathrm{~F}_{5}\right)_{3}$ in a $1: 1$ molar ratio $\left(\mathrm{CD}_{2} \mathrm{Cl}_{2}, 500 \mathrm{MHz}, \delta \mathrm{ppm}\right)$

\begin{tabular}{|c|c|c|c|c|}
\hline Complex & $\mathrm{C}_{5} \mathrm{H}_{3}$ & $C_{5} \mathrm{H}_{3}$ & $\mathrm{Si}-\mathrm{CH}_{3}$ & $\mathrm{Si}-\mathrm{CH}_{3}$ \\
\hline $\begin{array}{l}{\left[\mathrm{Zr}\left(\mathrm{CpSi}_{2} \mathrm{Cp}\right) \mathrm{Cl}(\mu-\mathrm{Cl})\right.} \\
\left.\mathrm{Zr}\left(\mathrm{CpSi}{ }_{2} \mathrm{Cp}\right) \mathrm{Et}\right]^{+}\end{array}$ & $\begin{array}{l}7.01(\mathrm{~m}, 2 \mathrm{H}) \\
6.92(\mathrm{~m}, 2 \mathrm{H}) \\
6.61(\mathrm{~m}, 2 \mathrm{H}) \\
6.56(\mathrm{~m}, 4 \mathrm{H}) \\
6.50(\mathrm{~m}, 2 \mathrm{H})\end{array}$ & $\begin{array}{l}141.8,141.0 \\
134.8 ; 132.6 \\
120.8 \text { (ipso); } 118.1 \text { (ipso) } \\
117.6 ; 116.6 \text { (ipso) } \\
115.4 ; 111.5 \text { (ipso) }\end{array}$ & $\begin{array}{l}0.99(\mathrm{~s}, 3 \mathrm{H}) ; 0.97(\mathrm{~s}, 3 \mathrm{H}) \\
0.82(\mathrm{~s}, 3 \mathrm{H}) ; 0.77(\mathrm{~s}, 3 \mathrm{H}) \\
0.76(\mathrm{~s}, 3 \mathrm{H}) ; 0.42(\mathrm{~s}, 3 \mathrm{H}) \\
0.40(\mathrm{~s}, 3 \mathrm{H}) ; 0.26(\mathrm{~s}, 3 \mathrm{H})\end{array}$ & $\begin{aligned} 2.0 ; 1.9 \\
1.5 ; 1.3 \\
-3.4 ;-3.5 \\
-5.3 ;-5.4\end{aligned}$ \\
\hline $\begin{array}{l}{\left[\left\{\mathrm{Zr}\left(\mathrm{CpSi}{ }_{2} \mathrm{Cp}\right)(\mathrm{C} \equiv \mathrm{CPh})\right\}_{2}\right.} \\
(\mu-\mathrm{Et})]^{+}\end{array}$ & $\begin{array}{l}6.65(\mathrm{~m}, 4 \mathrm{H}) \\
6.57(\mathrm{~m}, 4 \mathrm{H}) \\
5.77(\mathrm{~m}, 4 \mathrm{H})\end{array}$ & & $\begin{array}{l}0.94(\mathrm{~s}, 6 \mathrm{H}) ; 0.84(\mathrm{~s}, 6 \mathrm{H}) \\
0.77(\mathrm{~s}, 6 \mathrm{H}) ;-0.14(\mathrm{~s}, 6 \mathrm{H})\end{array}$ & \\
\hline
\end{tabular}

2086 and $1592 \mathrm{~cm}^{-1}$, respectively. The ${ }^{1} \mathrm{H}-\mathrm{NMR}$ spectrum of $\mathbf{5}$ showed the expected $\mathrm{ABC}$ spin system for two equivalent cyclopentadienyl rings, four singlets for the silicon-bonded methyl groups and characteristic resonances for the aryl and ethyl groups. The characteristic resonance due to the $\eta^{2}$-iminoacyl carbon was observed in the ${ }^{13} \mathrm{C}\left\{{ }^{1} \mathrm{H}\right\}$-NMR spectrum at $\delta 241.0$ [15] (see Section 4).

\subsection{Reactions with $B\left(C_{6} F_{5}\right)_{3}$}

All the reactions with $\mathrm{B}\left(\mathrm{C}_{6} \mathrm{~F}_{5}\right)_{3}$, carried out in $\mathrm{CD}_{2} \mathrm{Cl}_{2}$ solutions in sealed NMR tubes and monitored by ${ }^{1} \mathrm{H}-\mathrm{NMR}$ spectroscopy, finally gave the neutral dichloro complex $\left[\mathrm{Zr}\left(\mathrm{CpSi}_{2} \mathrm{Cp}\right) \mathrm{Cl}_{2}\right]$ resulting from chlorination by the $\mathrm{CD}_{2} \mathrm{Cl}_{2}$ solvent. Formation of different intermediate cationic species was detected from the ${ }^{1} \mathrm{H}$ and ${ }^{13} \mathrm{C}-\mathrm{NMR}$ spectra recorded at different temperatures.

Addition of $\mathrm{B}\left(\mathrm{C}_{6} \mathrm{~F}_{5}\right)_{3}$ to a $\mathrm{CD}_{2} \mathrm{Cl}_{2}$ solution of the chloro-ethyl complex $\left[\mathrm{Zr}\left(\mathrm{CpSi}_{2} \mathrm{Cp}\right) \mathrm{ClEt}\right]$ at $-78^{\circ} \mathrm{C}$ in a 1:1 molar ratio caused the ethyl group to be eliminated to give the free anion $\left[\mathrm{B}\left(\mathrm{C}_{6} \mathrm{~F}_{5}\right)_{3} \mathrm{Et}\right]^{-}$, as evidenced by its ${ }^{1} \mathrm{H}-,{ }^{13} \mathrm{C}$ - and ${ }^{19} \mathrm{~F}-\mathrm{NMR}$ spectra [16]. The intermediate 14 -electron cationic species $\left[\mathrm{Zr}\left(\mathrm{CpSi}_{2} \mathrm{Cp}\right) \mathrm{Cl}\right]^{+}$ initially formed was not observed and the solution remained reversibly unaltered between -70 and $10^{\circ} \mathrm{C}$. As shown in Table 1 the ${ }^{1} \mathrm{H}$ - and ${ }^{13} \mathrm{C}$-NMR spectra showed six ring-proton (two overlapping) and ten ring-carbon resonances due to two $\mathrm{ABC}$ spin systems for the $\mathrm{C}_{5} \mathrm{H}_{3}$ rings and eight proton and carbon resonances for the silicon-bound methyl groups. This behaviour is consistent with the presence of a dinuclear cation containing two bridged non-equivalent metal fragments, as expected for the $\mu$-chloro bridged dinuclear species $\left[\mathrm{Zr}\left(\mathrm{CpSi}_{2} \mathrm{Cp}\right) \mathrm{Cl}(\mu-\mathrm{Cl}) \mathrm{Zr}\left(\mathrm{CpSi}{ }_{2} \mathrm{Cp}\right) \mathrm{Et}\right]^{+}$, formed by coordination of one molecule of the starting chloro-ethyl complex to the initially generated chloro zirconium cation, which remained unaltered even in the presence of $1 / 2$ equivalent excess of $B\left(C_{6} F_{5}\right)_{3}$. The presence of the zirconium-bound ethyl group was confirmed by the observation of an $\mathrm{A}_{2} \mathrm{~B}_{3}$ spin system in the ${ }^{1} \mathrm{H}$ spectrum $(\delta 1.09 \mathrm{t}, 3 \mathrm{H}, J=7.5 \mathrm{~Hz})$ and two signals at $\delta 16.2$ and $\delta 61.5$ in the ${ }^{13} \mathrm{C}$-NMR spectrum.

When the temperature was raised to $-10^{\circ} \mathrm{C}$ for 30 min the ${ }^{1} \mathrm{H}$ - and ${ }^{13} \mathrm{C}$-NMR spectra of the resulting solution showed three proton and five carbon resonances corresponding to one $\mathrm{ABC}$ spin system due to four equivalent $\mathrm{C}_{5} \mathrm{H}_{3}$ rings, and four proton and carbon singlets for the silicon-bound methyl groups of a dinuclear cation which does not contain ethyl groups. This behaviour is consistent with the presence of $\left[\mathrm{Zr}\left(\mathrm{CpSi}_{2} \mathrm{Cp}\right) \mathrm{Cl}(\mu-\mathrm{Cl}) \mathrm{Zr}\left(\mathrm{CpSi}_{2} \mathrm{Cp}\right) \mathrm{Cl}\right]^{+}$formed by the irreversible reaction of the previous cation with the chlorinated $\mathrm{CD}_{2} \mathrm{Cl}_{2}$ solvent [17].

This cationic species exhibited reversible dynamic behaviour between -70 and $20^{\circ} \mathrm{C}$, consistent with an anti-syn transformation through a transition state formed by three chlorine bridges and characterized by $\Delta G^{\ddagger 263 \mathrm{~K}}=13 \mathrm{kcal} \mathrm{mol}^{-1}$ at coalescence temperature (see Scheme 4). Finally a quantitative transformation led to the dichloro complex $\left[\mathrm{Zr}\left(\mathrm{CpSi}_{2} \mathrm{Cp}\right) \mathrm{Cl}_{2}\right]$ when the solution was heated to r.t. for $24 \mathrm{~h}$.

A similar study was carried out adding one equivalent of $\mathrm{B}\left(\mathrm{C}_{6} \mathrm{~F}_{5}\right)_{3}$ to one equivalent of the ethyl alkynyl complex $\left[\mathrm{Zr}\left(\mathrm{CpSi}_{2} \mathrm{Cp}\right) \mathrm{Et}(\mathrm{C} \equiv \mathrm{CPh})\right]$ (4) at $-78^{\circ} \mathrm{C}$ in $\mathrm{CD}_{2} \mathrm{Cl}_{2}$. Formation of the $\left[\mathrm{B}\left(\mathrm{C}_{6} \mathrm{~F}_{5}\right)_{3} \mathrm{Et}\right]^{-}$borate anion was also observed along with a series of different cationic complexes (Scheme 4). The ${ }^{1} \mathrm{H}-\mathrm{NMR}$ spectrum at $-50^{\circ} \mathrm{C}$ showed one multiplet at $\delta-1.65(2 \mathrm{H})$ corresponding to a $\mathrm{CH}_{2}-\mathrm{CH}_{3}$ bridging group, an $\mathrm{ABC}$ spin system for four equivalent $\mathrm{C}_{5} \mathrm{H}_{3}$ rings and four singlets for the methyl-silicon protons (see Table 1). This is consistent with the presence of the cationic dimer $\left[\left\{\mathrm{Zr}\left(\mathrm{CpSi}{ }_{2} \mathrm{Cp}\right)(\mathrm{C} \equiv \mathrm{CPh}\}_{2}\left(\mu-\mathrm{CH}_{2} \mathrm{CH}_{3}\right)\right]^{+}\right.$. Between -50 and $-20^{\circ} \mathrm{C}$ a mixture of compounds was observed, which after $1 \mathrm{~h}$ at $-20^{\circ} \mathrm{C}$ contained two major components which could not be identified. A slow 


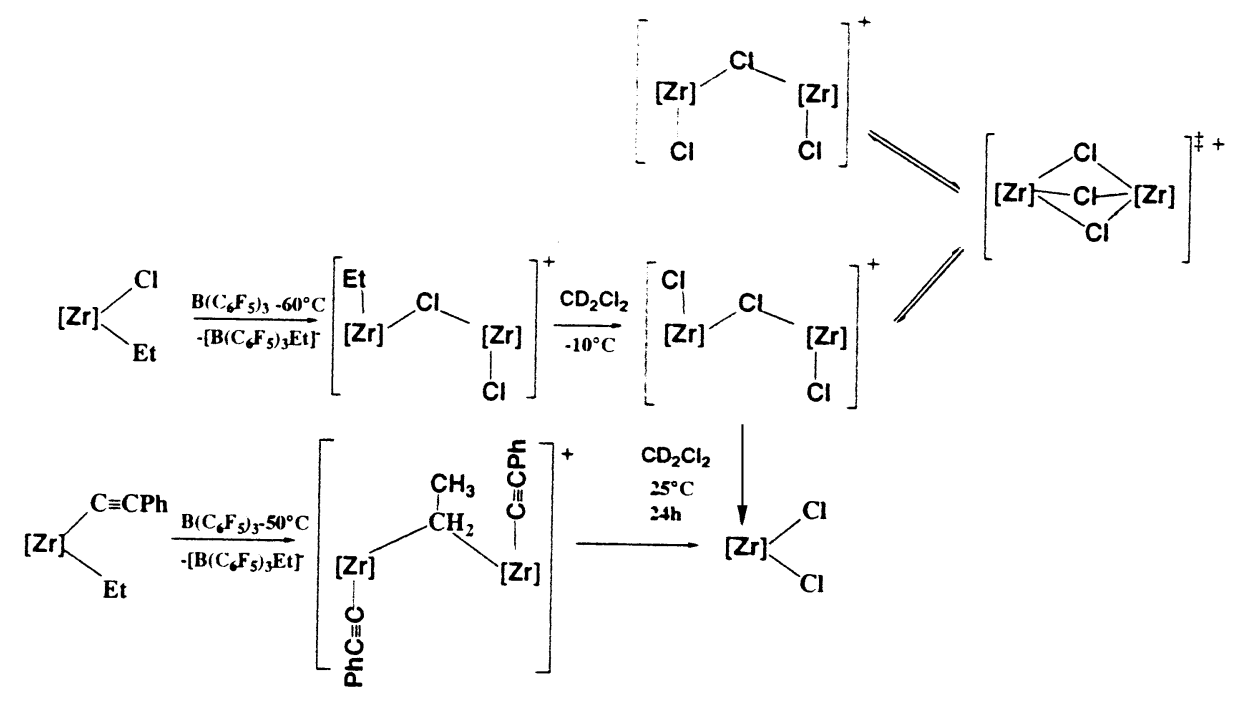

$[\mathrm{Zr}]=\left[\mathrm{Zr}\left(\mathrm{CpSi}_{2} \mathrm{Cp}\right)\right]$

Scheme 4.

transformation took place finally when the solution was heated at r.t. for more than $24 \mathrm{~h}$ to give the dichloro derivative $\left[\mathrm{Zr}\left(\mathrm{CpSi}_{2} \mathrm{Cp}\right) \mathrm{Cl}_{2}\right]$.

\section{Conclusions}

Easy $\beta$-hydrogen elimination from the ethyl group of $\left[\mathrm{Zr}\left(\mathrm{CpSi}_{2} \mathrm{Cp}\right) \mathrm{EtCl}\right]$ when it is vinylated is an appropriate method to synthesize the zirconacyclopentane derivative and the related zirconacyclopentadiene from its reaction with phenylacetylene. In contrast, the alkynyl compound $\left[\mathrm{Zr}\left(\mathrm{CpSi}_{2} \mathrm{Cp}\right) \mathrm{Et}(\mathrm{C} \equiv \mathrm{CPh})\right]$ is thermally stable and can insert isocyanide into its $\mathrm{Zr}$-ethyl bond. Thermal transformation of the divinyl derivative $\left[\mathrm{Zr}\left(\mathrm{CpSi}_{2} \mathrm{Cp}\right)\left(\mathrm{CH}=\mathrm{CH}_{2}\right)_{2}\right]$, which can be isolated in solution between -50 and $-10^{\circ} \mathrm{C}$, leads to the corresponding $\left(\eta^{4}\right.$-butadiene $)$ zirconium complex $[\mathrm{Zr}(\mathrm{Cp}$ $\left.\mathrm{Si}_{2} \mathrm{Cp}\right)\left\{\eta^{4}\right.$-(butadiene) $\}$ ]. Reactions of the chloro-ethyl and alkynyl-ethyl compounds with $\mathrm{B}\left(\mathrm{C}_{6} \mathrm{~F}_{5}\right)_{3}$ in sealed NMR tubes allow new dinuclear cationic species to be identified.

\section{Experimental}

\subsection{General}

All operations were performed under an inert atmosphere of argon using Schlenk and vacuum-line techniques or a VAC glovebox Model HE-63-P. The following solvents were pre-dried by standing over $4 \AA$ molecular sieves and purified by distillation under argon before use by employing the appropriate drying/de- oxygenated agents: tetrahydrofuran (sodium/benzophenone), toluene (sodium) and hexane (sodium/potassium alloy). [ $\left.\mathrm{Zr}\left(\mathrm{CpSi}_{2} \mathrm{Cp}\right) \mathrm{Cl}\left(\mathrm{CH}_{2}-\mathrm{CH}_{3}\right)\right]$ [5], [ $\mathrm{Zr}(\mathrm{Cp}-$ $\left.\mathrm{Si}_{2} \mathrm{Cp}\right) \mathrm{Cl}_{2}$ ] [4b] and $\mathrm{B}\left(\mathrm{C}_{6} \mathrm{~F}_{5}\right)_{3}$ [18] were prepared according to literature procedures. $\mathrm{Mg}\left(\mathrm{CH}=\mathrm{CH}_{2}\right) \mathrm{Cl}$ (Aldrich), $\mathrm{PhC} \equiv \mathrm{CPh}$ (Aldrich), $\mathrm{HC} \equiv \mathrm{CPh}$ (Aldrich), were purchased from commercial sources and used without further purification. ${ }^{1} \mathrm{H}$ - and ${ }^{13} \mathrm{C}-\mathrm{NMR}$ spectra were recorded on Unity-300 and Unity 500 Plus spectrometers. ${ }^{1} \mathrm{H}$ and ${ }^{13} \mathrm{C}$ chemical shifts are reported in $\delta$ units measured with respect to the solvent signals. Mass spectra were recorded on a Hewlett-Packard 5890 spectrometer. Elemental $\mathrm{C}$ and $\mathrm{H}$ analyses were performed with a Perkin-Elmer 240B microanalyzer.

$$
\begin{aligned}
& \text { 4.2. }\left[\mathrm{Zr}\left\{\left(\eta^{5}-\mathrm{C}_{5} \mathrm{H}_{3}\right)_{2}\left[\mathrm{Si}\left(\mathrm{CH}_{3}\right)_{2}\right]_{2}\right\}-\right. \\
& \left.\left\{\eta^{2}-\left[\mathrm{CH}_{2}-\left(\mathrm{CH}_{2}\right)_{2}-\mathrm{CH}_{2}\right]\right\}\right](\mathbf{1})
\end{aligned}
$$

A $1 \mathrm{M}$ THF solution of $\mathrm{Mg}\left(\mathrm{CH}=\mathrm{CH}_{2}\right) \mathrm{Cl}(2.51 \mathrm{ml}$, $2.51 \mathrm{mmol})$ was added to a toluene solution $(25 \mathrm{ml})$ of $\left[\mathrm{Zr}\left(\mathrm{CpSi}_{2} \mathrm{Cp}\right)\left(\mathrm{CH}_{2}-\mathrm{CH}_{3}\right) \mathrm{Cl}\right](1.00 \mathrm{~g}, 2.51 \mathrm{mmol})$ at $0^{\circ} \mathrm{C}$. The mixture was stirred for $2 \mathrm{~h}$ to give a red solution which after the solvent was removed and the residue extracted into hexane afforded complex $\mathbf{1}$, as a yellow solid. Yield, $0.79 \mathrm{~g}, 80 \%$. Anal. Calc. for $\mathrm{C}_{18} \mathrm{H}_{26} \mathrm{Si}_{2} \mathrm{Zr}$ : C, 55.46; H, 6.72. Found: C, 54.92; H, 6.40\%. ${ }^{1} \mathrm{H}-\mathrm{NMR}$ $\left(\mathrm{C}_{6} \mathrm{D}_{6}, 500 \mathrm{MHz}\right): \delta 6.64\left(\mathrm{~d}, 4 \mathrm{H}, \mathrm{C}_{5} \mathrm{H}_{3}\right), 6.60(\mathrm{t}, 2 \mathrm{H}$, $\left.\mathrm{C}_{5} \mathrm{H}_{3}\right), 1.80\left(\mathrm{~m}, 4 \mathrm{H},-\mathrm{CH}_{2}-\mathrm{CH}_{2}\right), 1.10(\mathrm{~m}, 4 \mathrm{H}$, $\left.\mathrm{Zr}-\mathrm{CH}_{2}\right), 0.47\left(\mathrm{~s}, 6 \mathrm{H}, \mathrm{SiMe}_{2}\right),-0.05\left(\mathrm{~s}, 6 \mathrm{H}, \mathrm{SiMe}_{2}\right)$; ${ }^{13} \mathrm{C}-\mathrm{NMR}\left(\mathrm{C}_{6} \mathrm{D}_{6}, 125 \mathrm{MHz}\right): \delta \quad 128.4\left(\mathrm{C}_{5} \mathrm{H}_{3}\right), 114.9$ $\left(\mathrm{C}_{5} \mathrm{H}_{3}\right), 110.9\left(\mathrm{C}_{5} \mathrm{H}_{3} \mathrm{C}_{\text {ipso }}\right), 34.8\left(\mathrm{t},{ }^{1} J_{\mathrm{CH}}=124.1 \mathrm{~Hz}\right.$, $\left.\mathrm{Zr}-\mathrm{CH}_{2}-\right), 23.0\left(\mathrm{t},{ }^{1} J_{\mathrm{CH}}=125.5 \mathrm{~Hz}, \mathrm{CH}_{2}-\mathrm{CH}_{2}\right), 2.0$ $\left(\mathrm{SiMe}_{2}\right),-4.1\left(\mathrm{SiMe}_{2}\right)$. 


\section{3. $\left[\mathrm{Zr}\left\{\left(\eta^{5}-\mathrm{C}_{5} \mathrm{H}_{3}\right)_{2}\left[\mathrm{Si}\left(\mathrm{CH}_{3}\right)_{2}\right]_{2}-\right.\right.$ \\ $\left.\left\{\eta^{2}(C P h=C P h-C P h=C P h)\right\}\right](2)$}

A THF solution of $\mathbf{1}$ prepared as described above from $\mathrm{Mg}\left(\mathrm{CH}=\mathrm{CH}_{2}\right) \mathrm{Cl}(2.51 \mathrm{ml}, 2.51 \mathrm{mmol})$ and $\left[\mathrm{Zr}\left(\mathrm{CpSi}_{2} \mathrm{Cp}\right)\left(\mathrm{CH}_{2}-\mathrm{CH}_{3}\right) \mathrm{Cl}\right](0.99 \mathrm{~g}, 2.49 \mathrm{mmol})$ was evaporated and the residue was treated with a toluene solution $(30 \mathrm{ml})$ of $\mathrm{PhC} \equiv \mathrm{CPh}(0.89 \mathrm{~g}, 5.20 \mathrm{mmol})$ and then refluxed for $2 \mathrm{~h}$. The ${ }^{1} \mathrm{H}-\mathrm{NMR}$ spectrum of this solution showed that the intermediate complex $\left[\mathrm{Zr}\left(\mathrm{CpSi}_{2} \mathrm{Cp}\right)\left\{\eta^{2}-\left(\mathrm{PhC}=\mathrm{CPh}-\mathrm{CH}_{2}-\mathrm{CH}_{2}\right)\right\}\right]$ was present as a minor component. ${ }^{1} \mathrm{H}-\mathrm{NMR}\left(\mathrm{C}_{6} \mathrm{D}_{6}, 300 \mathrm{MHz}, \delta\right.$ ppm): $\delta 7.10-6.80\left(\mathrm{~m}, 10 \mathrm{H}, \mathrm{C}_{6} \mathrm{H}_{5}\right.$ and $\left.2 \mathrm{H}, \mathrm{C}_{5} \mathrm{H}_{3}\right), 6.72$ $\left(\mathrm{m}, 2 \mathrm{H}, \mathrm{C}_{5} \mathrm{H}_{3}\right), 6.47\left(\mathrm{~m}, 2 \mathrm{H}, \mathrm{C}_{5} \mathrm{H}_{3}\right), 2.98\left(\mathrm{t}, 2 \mathrm{H}, J_{\mathrm{HH}}=\right.$ $\left.6.6 \mathrm{~Hz},-\mathrm{CH}_{2}-\mathrm{CH}_{2}-\right), 1.47\left(\mathrm{t}, 2 \mathrm{H}, J_{\mathrm{HH}}=6.6 \mathrm{~Hz}\right.$, $\left.\mathrm{Zr}-\mathrm{CH}_{2}-\right), 0.52$ (s, $\left.3 \mathrm{H}, \mathrm{SiMe}_{2}\right), 0.45$ (s, 3H, $\left.\mathrm{SiMe}_{2}\right), 0.01$ $\left(\mathrm{s}, 3 \mathrm{H}, \mathrm{SiMe}_{2}\right),-0.40\left(\mathrm{~s}, 3 \mathrm{H}, \mathrm{SiMe}_{2}\right)$. After refluxing for $15 \mathrm{~h}$ the solution was filtered and the solvent was removed under vacuum. The solid residue was washed with hexane $(15 \mathrm{ml})$, to give a yellow solid which was characterized by NMR spectroscopy and elemental analysis as compound 2. Yield $1.03 \mathrm{~g}, 60 \%$. Anal. Calc. for $\mathrm{C}_{42} \mathrm{H}_{38} \mathrm{Si}_{2} \mathrm{Zr}$ : C, 73.09; $\mathrm{H}, 5.55$. Found: C, 73.42; $\mathrm{H}$, $5.68 \%$. Mass spectrum (EI): $m / z 689\left[\mathrm{M}^{+}, 2.7\right], 511$ $\left[\mathrm{M}^{+}-\mathrm{PhC} \equiv \mathrm{CPh}, 2\right], 333\left[\mathrm{M}^{+}-2 \mathrm{PhC} \equiv \mathrm{CPh}, 64.7\right], 178$ $[\mathrm{PhC} \equiv \mathrm{CPh}, 100] .{ }^{1} \mathrm{H}-\mathrm{NMR}\left(\mathrm{C}_{6} \mathrm{D}_{6}, 300 \mathrm{MHz}, \delta \mathrm{ppm}\right): \delta$ $7.10-7.04\left(\mathrm{~m}, 6 \mathrm{H}, \mathrm{C}_{6} \mathrm{H}_{5}\right), 6.96\left(\mathrm{t}, 2 \mathrm{H}, \mathrm{C}_{5} \mathrm{H}_{3}\right), 6.90-6.82$ $\left(\mathrm{m}, 8 \mathrm{H}, \mathrm{C}_{6} \mathrm{H}_{5}\right), 6.77-6.74\left(\mathrm{~m}, 4 \mathrm{H}, \mathrm{C}_{6} \mathrm{H}_{5}\right), 6.80(\mathrm{~d}, 4 \mathrm{H}$, $\left.\mathrm{C}_{5} \mathrm{H}_{3}\right), 6.60-6.55\left(\mathrm{~m}, 2 \mathrm{H}, \mathrm{C}_{6} \mathrm{H}_{5}\right), 0.48\left(\mathrm{~s}, 6 \mathrm{H}, \mathrm{SiMe}_{2}\right)$, $-0.36\left(\mathrm{~s}, 6 \mathrm{H}, \mathrm{SiMe}_{2}\right) ;{ }^{13} \mathrm{C}-\mathrm{NMR}\left(\mathrm{C}_{6} \mathrm{D}_{6}, 75 \mathrm{MHz}, \delta\right.$ ppm): $\delta 193.2(\mathrm{Zr}-\mathrm{CPh}=), 150.7 \quad(\mathrm{PhC}=\mathrm{CPh}), 141.9$ $\left(\mathrm{C}_{6} \mathrm{H}_{5} \mathrm{C}_{\text {ipso }}\right), 132.4,130.2,126.8,124.9,123.1\left(\mathrm{C}_{6} \mathrm{H}_{5}\right)$, $135.5\left(\mathrm{C}_{5} \mathrm{H}_{3} \mathrm{C}_{\text {ipso }}\right), 127.9\left(\mathrm{C}_{5} \mathrm{H}_{3}\right), 116.5\left(\mathrm{C}_{5} \mathrm{H}_{3}\right), 2.60$ $\left(\mathrm{SiMe}_{2}\right),-5.06\left(\mathrm{SiMe}_{2}\right)$.

\subsection{Reaction of $\left[\mathrm{Zr}\left\{\left(\eta^{5}-\mathrm{C}_{5} \mathrm{H}_{3}\right)_{2}\left[\mathrm{Si}\left(\mathrm{CH}_{3}\right)_{2}\right]_{2}\right\} \mathrm{Cl}_{2}\right]$ with two equivalents of $\mathrm{Mg}\left(\mathrm{CH}=\mathrm{CH}_{2}\right) \mathrm{Cl}$}

\subsubsection{NMR tube scale}

An NMR tube containing a mixture of the dichlorozirconocene $(0.05 \mathrm{~g}, 0.12 \mathrm{mmol})$ and a $1 \mathrm{M}$ THF solution of $\mathrm{Mg}\left(\mathrm{CH}=\mathrm{CH}_{2}\right) \mathrm{Cl}(0.24 \mathrm{ml})$ in $0.75 \mathrm{ml}$ of THF- $d_{8}$ was sealed under vacuum at $-78^{\circ} \mathrm{C}$. The reaction was monitored by ${ }^{1} \mathrm{H}$ - and ${ }^{13} \mathrm{C}-\mathrm{NMR}$ spectroscopy. After $5 \mathrm{~min}$ at $-50^{\circ} \mathrm{C}$ all of the starting complex had been transformed into $\left[\mathrm{Zr}\left(\mathrm{CpSi}_{2} \mathrm{Cp}\right)\right.$ $\left.\left(\mathrm{CH}=\mathrm{CH}_{2}\right)_{2}\right]$, which was the only organometallic compound present in the solution (NMR yield, ca. 100\%). ${ }^{1} \mathrm{H}-\mathrm{NMR}$ (THF- $\left.d_{8},-50{ }^{\circ} \mathrm{C}, 500 \mathrm{MHz}, \delta \mathrm{ppm}\right): \delta 7.47$ $\left(\mathrm{dd}, 2 \mathrm{H},{ }^{3} J_{\text {trans }}=21.2,{ }^{3} J_{\text {cis }}=15.4 \mathrm{~Hz}, \mathrm{Zr}-\mathrm{CH}=\right), 6.43(\mathrm{~d}$, $\left.4 \mathrm{H}, J=2.8 \mathrm{~Hz}, \mathrm{C}_{5} \mathrm{H}_{3}\right), 6.22\left(\mathrm{t}, 2 \mathrm{H}, J=2.8 \mathrm{~Hz}, \mathrm{C}_{5} \mathrm{H}_{3}\right.$ ), $5.87\left(\mathrm{dd}, 2 \mathrm{H},{ }^{3} \mathrm{~J}_{\text {cis }}=15.4,{ }^{2} \mathrm{~J}=2.6 \mathrm{~Hz},=\mathrm{CH}_{2}-\right), 5.35(\mathrm{dd}$, $\left.2 \mathrm{H},{ }^{3} J_{\text {trans }}=21.2,{ }^{2} J=2.6 \mathrm{~Hz},=\mathrm{CH}_{2}\right), 0.65(\mathrm{~s}, 6 \mathrm{H}$, $\left.\mathrm{SiMe}_{2}\right), 0.37$ (s, 6H, SiMe $\left.)_{2}\right) \cdot{ }^{13} \mathrm{C}-\mathrm{NMR}\left(\mathrm{THF}-d_{8},-\right.$ $\left.50^{\circ} \mathrm{C}, 125 \mathrm{MHz}, \delta \mathrm{ppm}\right): \delta 184.7(-\mathrm{CH}=), 131.5\left(\mathrm{C}_{5} \mathrm{H}_{3}\right)$, $126.8\left({ }^{-\mathrm{CH}_{2}}\right), 113.6\left(\mathrm{C}_{5} \mathrm{H}_{3}\right), 110.1\left(\mathrm{C}_{5} \mathrm{H}_{3} \mathrm{C}_{\text {ipso }}\right), 2.4$
$\left(\mathrm{SiMe}_{2}\right),-4.1\left(\mathrm{SiMe}_{2}\right)$. After $30 \mathrm{~min}$ at $20^{\circ} \mathrm{C}$, resonances of complex 3 started to appear and after $12 \mathrm{~h}$ at r.t. complex $\mathbf{3}$ was the major component in the solution, together with other unidentified complexes.

\subsubsection{Preparative scale}

A $1 \mathrm{M}$ THF solution of $\mathrm{Mg}\left(\mathrm{CH}=\mathrm{CH}_{2}\right) \mathrm{Cl}(5 \mathrm{ml}, 5$ mmol) was added to a toluene solution $(50 \mathrm{ml})$ of $\left[\mathrm{Zr}\left(\mathrm{CpSi}_{2} \mathrm{Cp}\right) \mathrm{Cl}_{2}\right](1.00 \mathrm{~g}, 2.47 \mathrm{mmol})$ at r.t. and stirred for $12 \mathrm{~h}$ to give a red-brown solution. The solution was filtered and the solvent was removed under vacuum to give a red oil. Recrystallization from hexane afforded the zirconacyclo-3-pentene complex $\left[\mathrm{Zr}\left(\mathrm{Cp}-\mathrm{Si}_{2} \mathrm{Cp}\right)\left\{\eta^{2}\right.\right.$ $\left.\left.\left(\mathrm{CH}_{2}-\mathrm{CH}=\mathrm{CH}-\mathrm{CH}_{2}\right)\right\}\right]$ (3) as a red solid. Yield $0.29 \mathrm{~g}$, $30 \%$. Anal. Calc. for $\mathrm{C}_{18} \mathrm{H}_{24} \mathrm{Si}_{2} \mathrm{Zr}$ : C, 55.75; H, 6.24. Found: C, 55.54; H, 6.31\%. ${ }^{1} \mathrm{H}-\mathrm{NMR}\left(\mathrm{C}_{6} \mathrm{D}_{6}, 300 \mathrm{MHz}\right.$, $\delta$ ppm): $\delta 6.52\left(\mathrm{~d}, 2 \mathrm{H}, \mathrm{C}_{5} \mathrm{H}_{3}\right), 5.25\left(\mathrm{~d}, 2 \mathrm{H}, \mathrm{C}_{5} \mathrm{H}_{3}\right), 5.05$ $\left(\mathrm{t}, 1 \mathrm{H}, \mathrm{C}_{5} \mathrm{H}_{3}\right), 4.64(\mathrm{~m}, 2 \mathrm{H},-\mathrm{CH}=), 4.14\left(\mathrm{t}, 1 \mathrm{H}, \mathrm{C}_{5} \mathrm{H}_{3}\right)$, $3.28\left(\mathrm{~m}, 2 \mathrm{H},-\mathrm{CH}_{2}-\right.$ syn $), 0.71$ (s, 6H, $\left.\mathrm{SiMe}_{2}\right), 0.42$ (s, $\left.6 \mathrm{H}, \mathrm{SiMe}_{2}\right),-0.80\left(\mathrm{~m}, 2 \mathrm{H},-\mathrm{CH}_{2}\right.$-anti $) .{ }^{13} \mathrm{C}-\mathrm{NMR}$ $\left(\mathrm{C}_{6} \mathrm{D}_{6}, 125 \mathrm{MHz}, \delta \mathrm{ppm}\right): \delta 129.8\left(\mathrm{C}_{5} \mathrm{H}_{3} \mathrm{C}_{\text {ipso }}\right), 126.7$ $\left(\mathrm{C}_{5} \mathrm{H}_{3} \mathrm{C}_{\text {ipso }}\right), 124.1\left(\mathrm{C}_{5} \mathrm{H}_{3}\right), 112.5\left(\mathrm{C}_{5} \mathrm{H}_{3}\right), 110.7(-\mathrm{CH}=)$, $110.1\left(\mathrm{C}_{5} \mathrm{H}_{3}\right), 102.4\left(\mathrm{C}_{5} \mathrm{H}_{3}\right), 49.8\left(\mathrm{dd},{ }^{1} J_{\mathrm{CH}}=158.7\right.$, $\left.{ }^{1} J_{\mathrm{CH}}=132.0 \mathrm{~Hz},-\mathrm{CH}_{2}-\right), 2.2\left(\mathrm{SiMe}_{2}\right),-3.1\left(\mathrm{SiMe}_{2}\right)$.

\section{5. $\left[\mathrm{Zr}\left\{\left(\eta^{5}-\mathrm{C}_{5} \mathrm{H}_{3}\right)_{2}\left[\mathrm{Si}\left(\mathrm{CH}_{3}\right)_{2}\right]_{2}\right\}(\mathrm{C} \equiv \mathrm{CPh})\left(\mathrm{CH}_{2}-\mathrm{CH}_{3}\right)\right]$ (4)}

A THF $(25 \mathrm{ml})$ solution of $\mathrm{LiC} \equiv \mathrm{CPh}(0.11 \mathrm{~g}, 1.00$ mmol) was added to a THF solution $(25 \mathrm{ml})$ of $\left[\mathrm{Zr}\left(\mathrm{CpSi}_{2} \mathrm{Cp}\right) \mathrm{Cl}\left(\mathrm{CH}_{2} \mathrm{CH}_{3}\right)\right](0.40 \mathrm{~g}, 1.00 \mathrm{mmol})$ at $0^{\circ} \mathrm{C}$. The mixture was stirred for $3 \mathrm{~h}$ to give a dark red solution, the solvent was removed in vacuo and the residue was extracted into hexane to give complex $\mathbf{4}$, which was recrystallized from pentane as yellow crystals. Yield $0.30 \mathrm{~g}, 64 \%$. Anal. Calc. for $\mathrm{C}_{24} \mathrm{H}_{28} \mathrm{Si}_{2} \mathrm{Zr}$ : C, 62.14; H, 6.08. Found: C, 61.87; H, 6.01\%. IR: (Nujol) $2078 \mathrm{~cm}^{-1}[v(\mathrm{C} \equiv \mathrm{C})] .{ }^{1} \mathrm{H}-\mathrm{NMR}\left(\mathrm{C}_{6} \mathrm{D}_{6}, 300 \mathrm{MHz}, \delta\right.$ ppm): $\delta 7.53\left(\mathrm{~m}, 2 \mathrm{H}, \mathrm{C}_{6} \mathrm{H}_{5}\right), 7.18\left(\mathrm{~m}, 2 \mathrm{H}, \mathrm{C}_{5} \mathrm{H}_{3}\right)$, 6.96-7.01 (m, 3H, $\left.\mathrm{C}_{6} \mathrm{H}_{5}\right), 6.51\left(\mathrm{~m}, 2 \mathrm{H}, \mathrm{C}_{5} \mathrm{H}_{3}\right), 6.32(\mathrm{~m}$, $\left.2 \mathrm{H}, \mathrm{C}_{5} \mathrm{H}_{3}\right), 1.33\left(\mathrm{t}, 3 \mathrm{H},{ }^{3} J_{\mathrm{HH}}=8 \mathrm{~Hz},-\mathrm{CH}_{2}-\mathrm{CH}_{3}\right), 0.72$ (q, $\left.2 \mathrm{H},{ }^{3} J_{\mathrm{HH}}=8 \mathrm{~Hz},-\mathrm{CH}_{2}-\mathrm{CH}_{3}\right), 0.54\left(\mathrm{~s}, 3 \mathrm{H}, \mathrm{SiMe}_{2}\right)$, 0.51 (s, 3H, SiMe $), 0.50$ (s, 3H, SiMe $), 0.12$ (s, 3H, $\left.\mathrm{SiMe}_{2}\right) .{ }^{13} \mathrm{C}-\mathrm{NMR}\left(\mathrm{C}_{6} \mathrm{D}_{6}, 75 \mathrm{MHz}, \delta \mathrm{ppm}\right): \delta 135.6$ $(\mathrm{Zr}-\mathrm{C} \equiv), 131.5 \quad\left(\mathrm{C}_{5} \mathrm{H}_{3}\right), 129.2\left(\mathrm{C}_{5} \mathrm{H}_{3}\right), 127.1 \quad\left(\mathrm{C}_{6} \mathrm{H}_{5}\right)$, $126.0\left(\mathrm{C}_{6} \mathrm{H}_{5}\right), 119.0(\equiv \mathrm{CPh}), 113.1\left(\mathrm{C}_{5} \mathrm{H}_{3}\right), 111.8\left(\mathrm{C}_{5} \mathrm{H}_{3}\right.$ $\left.\mathrm{C}_{i p s o}\right), 109.2\left(\mathrm{C}_{5} \mathrm{H}_{3} \mathrm{C}_{i p s o}\right), 49.5\left(\mathrm{t}, J_{\mathrm{CH}}=115.5 \mathrm{~Hz}\right.$, $\left.\mathrm{CH}_{2}-\mathrm{CH}_{3}\right), 13.1\left(\mathrm{q}, J_{\mathrm{CH}}=123.2 \mathrm{~Hz}, \mathrm{CH}_{2}-\mathrm{CH}_{3}\right), 2.42$ $\left(\mathrm{SiMe}_{2}\right), 2.40\left(\mathrm{SiMe}_{2}\right),-3.72\left(\mathrm{SiMe}_{2}\right),-3.62\left(\mathrm{SiMe}_{2}\right)$.

\section{6. $\left[\mathrm{Zr}\left\{\left(\eta^{5}-\mathrm{C}_{5} \mathrm{H}_{3}\right)_{2}\left[\mathrm{Si}\left(\mathrm{CH}_{3}\right)_{2}\right]_{2}\right\}(\mathrm{C} \equiv \mathrm{CPh})\left\{\eta^{2}-\right.\right.$ $\left.\left.\left[\mathrm{C}(\mathrm{Et}) \mathrm{N}\left[2,6-\left(\mathrm{CH}_{3}\right)_{2} \mathrm{C}_{6} \mathrm{H}_{3}\right]\right]\right\}\right]$ (5)}

A toluene $(25 \mathrm{ml})$ solution of 2,6-dimethylphenylisocyanide $(0.25 \mathrm{~g}, 1.90 \mathrm{mmol})$ was added to a toluene (25 ml) solution of $\left[\mathrm{Zr}\left(\mathrm{CpSi}_{2} \mathrm{Cp}\right) \mathrm{Et}(\mathrm{C} \equiv \mathrm{CPh})\right]$ (4) (0.90 g, 
$1.90 \mathrm{mmol}$ ) at $20^{\circ} \mathrm{C}$. The mixture was stirred for $12 \mathrm{~h}$ to give a red dark solution. Solvent was removed in vacuo and the residue extracted into hexane to yield complex 5 after evaporation. Yield $1.02 \mathrm{~g}, 90 \%$. Anal. Calc. for $\mathrm{C}_{33} \mathrm{H}_{37} \mathrm{NSi}_{2} \mathrm{Zr}$ : C, 66.61; H, 6.27; N, 2.35. Found: C, 66.42; H, 6.04; N, 2.34\%. IR: (Nujol) $2086[v(\mathrm{C} \equiv \mathrm{C})]$, $1592 \mathrm{~cm}^{-1}[v(\mathrm{C}=\mathrm{N})] .{ }^{1} \mathrm{H}-\mathrm{NMR}\left(\mathrm{C}_{6} \mathrm{D}_{6}, 300 \mathrm{MHz}, \delta\right.$ ppm): $\delta 7.50\left(\mathrm{~m}, 2 \mathrm{H}, \mathrm{C}_{6} \mathrm{H}_{5}\right), 7.30\left(\mathrm{~m}, 2 \mathrm{H}, \mathrm{C}_{6} \mathrm{H}_{5}\right), 7.05$ $\left(\mathrm{t}, 1 \mathrm{H}, \mathrm{C}_{6} \mathrm{H}_{5}\right), 6.94\left(\mathrm{~m}, 3 \mathrm{H}, \mathrm{Me}_{2} \mathrm{C}_{6} H_{3}\right), 6.90(\mathrm{~m}, 2 \mathrm{H}$, $\left.\mathrm{C}_{5} \mathrm{H}_{3}\right), 6.59\left(\mathrm{~m}, 2 \mathrm{H}, \mathrm{C}_{5} \mathrm{H}_{3}\right), 5.36\left(\mathrm{~m}, 2 \mathrm{H}, \mathrm{C}_{5} \mathrm{H}_{3}\right), 2.40(\mathrm{q}$, $\left.2 \mathrm{H}, J_{\mathrm{HH}}=7.5 \mathrm{~Hz},-\mathrm{CH}_{2}-\mathrm{CH}_{3}\right), 1.84\left(\mathrm{~s}, 6 \mathrm{H}, \mathrm{Me}_{2} \mathrm{C}_{6} \mathrm{H}_{3}\right)$, $1.11\left(\mathrm{~s}, 3 \mathrm{H}, \mathrm{SiMe}_{2}\right), 0.73\left(\mathrm{t}, 3 \mathrm{H}, J_{\mathrm{HH}}=7.5 \mathrm{~Hz}\right.$, $-\mathrm{CH}_{2}-\mathrm{CH}_{3}$ ), 0.72 (s, 3H, $\mathrm{SiMe}_{2}$ ), 0.69 (s, 3H, $\mathrm{SiMe}_{2}$ ), $\delta$ $0.56\left(\mathrm{~s}, 3 \mathrm{H}, \mathrm{SiMe}_{2}\right) \cdot{ }^{13} \mathrm{C}-\mathrm{NMR}\left(\mathrm{C}_{6} \mathrm{D}_{6}, 75 \mathrm{MHz}, \delta \mathrm{ppm}\right)$ : $\delta 241.0(\mathrm{C}=\mathrm{N}), 145.0(\mathrm{Zr}-\mathrm{C} \equiv), 134.8\left(\mathrm{C}_{5} \mathrm{H}_{3}\right), 131.4(\mathrm{Ph})$, $129.4(\mathrm{Ph}), 125.6(\mathrm{Ph}), 125.3(\mathrm{Ph}), 122.1\left(\mathrm{C}_{5} \mathrm{H}_{3}\right), 118.0$ $(\equiv \mathrm{CPh}), 109.4\left(\mathrm{C}_{5} \mathrm{H}_{3} \mathrm{C}_{\text {ipso }}\right), 107.8\left(\mathrm{C}_{5} \mathrm{H}_{3}\right), 107.3\left(\mathrm{C}_{5} \mathrm{H}_{3}\right.$ $\left.\mathrm{C}_{\text {ipso }}\right), 31.7\left(\mathrm{t}, J_{\mathrm{CH}}=123.8 \mathrm{~Hz}, \mathrm{CH}_{2}-\mathrm{CH}_{3}\right), 19.0(\mathrm{q}$, $\left.J_{\mathrm{CH}}=125.7 \mathrm{~Hz}, M_{2} \mathrm{C}_{6} \mathrm{H}_{3}\right), 10.1\left(\mathrm{q}, J_{\mathrm{CH}}=127.5 \mathrm{~Hz}\right.$, $\left.\mathrm{CH}_{2}-\mathrm{CH}_{3}\right), 3.2\left(\mathrm{SiMe}_{2}\right), 3.1\left(\mathrm{SiMe}_{2}\right),-3.50\left(\mathrm{SiMe}_{2}\right)$, $-3.9\left(\mathrm{SiMe}_{2}\right)$.

\subsection{Reaction of \\ $\left[\mathrm{Zr}\left\{\left(\eta^{5}-\mathrm{C}_{5} \mathrm{H}_{3}\right)_{2}\left[\mathrm{Si}\left(\mathrm{CH}_{3}\right)_{2}\right]_{2}\right\}\left(\mathrm{CH}_{2} \mathrm{CH}_{3}\right) \mathrm{Cl}\right]$ with $\mathrm{B}\left(\mathrm{C}_{6} \mathrm{~F}_{5}\right)_{3}$}

An NMR tube containing a mixture of the zirconium complex $(0.05 \mathrm{~g}, 0.12 \mathrm{mmol})$ and $\mathrm{B}\left(\mathrm{C}_{6} \mathrm{~F}_{5}\right)_{3}(0.065 \mathrm{~g}$, $0.12 \mathrm{mmol}$ ) in $0.75 \mathrm{ml}$ of $\mathrm{CD}_{2} \mathrm{Cl}_{2}$ was sealed under vacuum at $-78^{\circ} \mathrm{C}$ and the reaction was monitored by ${ }^{1} \mathrm{H}$ - and ${ }^{13} \mathrm{C}-\mathrm{NMR}$ spectroscopy.

\subsection{Reaction of $\left[\mathrm{Zr}\left\{\left(\eta^{5}-\mathrm{C}_{5} \mathrm{H}_{3}\right)_{2}\left[\mathrm{Si}\left(\mathrm{CH}_{3}\right)_{2}\right]_{2}\right\} \mathrm{Et}(\mathrm{C} \equiv \mathrm{CPh})\right]$ (4) with $B\left(C_{6} F_{5}\right)_{3}$}

An NMR tube containing a mixture of complex 4 $(0.04 \mathrm{~g}, 0.08 \mathrm{mmol})$ and $\mathrm{B}\left(\mathrm{C}_{6} \mathrm{~F}_{5}\right)_{3}(0.041 \mathrm{~g}, 0.08 \mathrm{mmol})$ in $0.75 \mathrm{ml}$ of $\mathrm{CD}_{2} \mathrm{Cl}_{2}$ was sealed under vacuum at $-78^{\circ} \mathrm{C}$. The reaction was monitored by ${ }^{1} \mathrm{H}-\mathrm{NMR}$ spectroscopy.

\section{Acknowledgements}

Support from DGESEIC (Project PB-97-0776) is gratefully acknowledged. F.J.F. acknowledges MECFPI for the award of Fellowship.

\section{References}

[1] (a) H.H. Brintzinger, D. Fischer, R. Mülhaupt, B. Rieger, R.M. Waymouth, Angew. Chem. Int. Ed. Engl. 34 (1995) 1143. (b)
M. Bochmann, J. Chem. Soc. Dalton Trans. (1996) 255. (c) W. Kaminsky, J. Chem. Soc. Dalton Trans. (1998) 1413.

[2] P.C. Möhring, N.J. Coville, J. Organomet. Chem. 479 (1994) 1.

[3] (a) C.S. Bajgur, W.R. Tikkanen, J.L. Petersen, Inorg. Chem. 24 (1985) 2539. (b) H. Wiesenfeldt, A. Reinmuth, E. Barsties, K. Evertz, H.H.J. Brintzinger, Organomet. Chem. 369 (1989) 359. (c) R. Gómez, T. Cuenca, P. Royo, W.A. Herrmann, E. Herdtweck, J. Organomet. Chem. 382 (1990) 103. (d) S.T. Chacon, E.B. Coughlin, L.M. Henling, J.E. Bercaw, J. Organomet. Chem. 497 (1995) 171. (e) H. Lee, T. Hascall, P.J. Desrosiers, G. Parkin, J. Am. Chem. Soc. 120 (1998) 5830. (f) J.C. Yoder, M.W. Day, J.E. Bercaw, Organometallics 17 (1998) 4946. (g) H. Schumann, K. Zietzke, R. Weimann, J. Demtschuk, W. Kaminsky, A.-M. Schauwienold, J. Organomet. Chem. 574 (1999) 228.

[4] (a) W. Mengele, J. Diebold, C. Troll, W. Röll, H.-H. Brintzinger, Organometallics 12 (1993) 1931. (b) A. Cano, T. Cuenca, P. Gómez-Sal, B. Royo, P. Royo, Organometallics 13 (1994) 1688. (c) T.A. Herzog, D.L. Zubris, J.E. Bercaw, J. Am. Chem. Soc. 118 (1996) 11 988. (d) T. Cuenca, M. Galajov, E. Royo, P. Royo, J. Organomet. Chem. 515 (1996) 33. (e) A. Cano, T. Cuenca, P. Gómez-Sal, P. Royo, J. Organomet. Chem. 526 (1996) 227. (f) D Veghini, L.M. Henling, T.J. Burkhardt, J.E. Bercaw, J. Am. Chem. Soc. 121 (1999) 564.

[5] F.J. Fernández, P. Goméz-Sal, A. Manzanero, P. Royo, H. Jacobsen, H. Berke, Organometallics 16 (1997) 1553.

[6] E. Negishi, T. Takahashi, Acc. Chem. Res. 27 (1994) 124 and Refs. therein.

[7] (a) T. Takahashi, M. Tamura, M. Saburi, Y. Uchida, E. Negishi, J. Chem. Soc. Chem. Commun. (1989) 852. (b) G. Erker, U. Dorf, A.L. Rheingold, Organometallics 7 (1988) 138, and Refs. therein.

[8] (a) K.S. Knight, D. Wang, R.M. Waymouth, J. Ziller, J. Am. Chem. Soc. 116 (1994) 1845. (b) E. Negishi, Chem. Eur. J. 5 (1999) 411, and Refs. therein. (c) T. Takahashi, W.-H. Sun, Y. Liu, K. Nakajima, M. Kotora, Organometallics 17 (1998) 3841.

[9] (a) H. Ubayama, W.-H. Sun, Z. Xi, T. Takahashi, Chem. Commun. (1998) 1931. (b) T. Takahashi, S. Huo, R. Hara, Y. Noguchi, K. Nakajima, W.-H. Sun, J. Am. Chem. Soc. 121 (1999) 1094. (c) T. Takahashi, W.-H. Sun, K. Nakajima, Chem. Commun. (1999) 1595.

[10] C. McDade, J.E. Bercaw, J. Organomet. Chem. 279 (1985) 281.

[11] P. Czish, G. Erker, H.-G. Korth, R. Sustmann, Organometallics 3 (1984) 945.

[12] R. Beckhaus, J. Chem. Soc. Dalton Trans. (1997) 1991.

[13] (a) H. Yasuda, K. Nagasuna, M. Akita, K. Lee, A. Nakamura, Organometallics 3 (1984) 1470. (b) G. Erker, K. Engel, U. Korek, P. Czisch, H. Berke, P. Caubère, R. Vanderesse, Organometallics 4 (1985) 1531, and Refs. therein.

[14] T. Bürgi, H. Berke, D. Wingbermühle, C. Psiorz, R. Noe, T. Fox, M. Knickmeier, M. Berkelamp, R. Fröhlich, G. Erker, J. Organomet. Chem. 497 (1995) 149 and Refs. therein.

[15] A. Barriola, A. Cano, T. Cuenca, F.J. Fernández, P. GomézSal, A. Manzanero, P. Royo, J. Organomet. Chem. 542 (1997) 247.

[16] M. Bochmann, O.B. Robinson, S.J. Lancaster, M.B. Hursthouse, S.J. Coles, Organometallics 14 (1995) 2456.

[17] T. Cuenca, M. Galakhov, G. Jiménez, E. Royo, P. Royo, M. Bochmann, J. Organomet. Chem. 543 (1997) 209 and Refs. therein.

[18] A.G. Massey, A.J. Park, J. Organomet. Chem. 2 (1964) 245. 